\title{
Researching Race: Identifying a Social Construction through Qualitative Methods and an Interactionist Perspective
}

\author{
Edward W. Morris \\ Ohio University
}

\begin{abstract}
Although much of the sociological community now views race as a social construction, empirical research does not always identify it in this way. Many practices of designating a research participant's race approach this process uncritically, implicitly framing race as uncomplicated. Although this is more common in survey-based work, in this article I explore the tendencies and difficulties of studying race using qualitative methods. I discuss two prevalent but potentially problematic ways of "operationalizing" race in qualitative methodology, and then elaborate on the difficulties of identifying race in practice, using examples from my own ethnographic research. I suggest that symbolic interactionism provides a unique perspective from which to express race as socially situated, as long as this process is approached reflectively.
\end{abstract}

Much of the scientific community now adheres to the notion that race is a social construction. Increasingly, this idea has even crept into the public arena. The New York Times published a series of opinion pieces debating the "nature" and categorization of race as Census 2000 released its results. In 2003, the Public Broadcasting System aired a documentary exhaustively presenting race as socially rather than biologically determined, drawing on the commentaries of biologists, historians, psychologists, anthropologists, and sociologists. In light of our increasing awareness of the social origins of race, it seems strange that many researchers continue to utilize this concept with little hint of reflecting on these origins. Race continues to be studied and used somewhat blithely in much sociological research, where it often appears devoid of social context and reified as a fixed essence. Although, as others have argued (e.g., Zuberi 2001), this practice may be more common in quantitative research, it also exists in qualitative studies. In this article I explore the tendencies

Direct all correspondence to Edward W. Morris, Department of Sociology and Anthropology, Bentley Annex, Ohio University, Athens, OH 45701; e-mail: morrise@ohio.edu.

Symbolic Interaction, Vol. 30, Issue 3, pp. 409-425, ISSN 0195-6086, electronic ISSN 1533-8665. () 2007 by the Society for the Study of Symbolic Interaction. All rights reserved. Please direct all requests for permission to photocopy or reproduce article content through the University of California Press's Rights and Permissions website, at http://www.ucpressjournals.com/reprintinfo.asp. DOI: 10.1525/si.2007.30.3.409. 
and difficulties of studying race using qualitative methods. I discuss two prevalent but potentially problematic ways of "operationalizing" race in qualitative methodology, and then elaborate on the difficulties of identifying race in practice, using examples from my own research. I suggest that symbolic interactionist approaches are uniquely positioned to reveal how race is shaped by social context and patterns of interaction, as long as researchers do not approach the concept of race uncritically.

Contemporary scientific research has consistently emphasized the social, rather than biological, origins of race. Biologically based commentaries argue that the racial categories we typically invoke have little or no genetic basis (Cooper 1984; Goodman 2000; Graves 2001). More genetic variation exists within social groups considered distinct races, for example, than between them (Cooper 1984; Goodman 2000). Further, upon increasing globalization and interconnection between people across the world, physical markers will undoubtedly blend across groups we consider racial, eroding current distinctions. This evidence focuses the question of race firmly on how society sorts groups and labels them "racial," as well as how people accept, perform, and inhabit racialized identities and systems of inequality (Hall 1986; Omi and Winant [1986] 1994; Smedley 1993).

Qualitative research has served as the sociological vanguard for exploring race and ethnicity as social constructions (e.g., Espiritu 1992; Frankenberg 1993; Nagel 1994, 1995; Spickard and Fong 1995; Waters 1990, 1999). ${ }^{1}$ Although not always stated explicitly, a symbolic interactionist perspective that modes of inequality, including race, develop and persist through interaction (see, e.g., Blumer 1958, 1969) has guided this research. Because of their ability to closely follow social processes as they emerge and change, qualitative methods form a particularly useful way of studying and understanding race as the product of social interaction. Path-breaking qualitative work on race has focused especially on the fluidity of racial and ethnic identities, showing how racial meanings and self-concepts vary across historical and social contexts. While corroborating the notion that race is not fixed by biology, this research highlights how people develop racial understandings of themselves and others through interaction. Race is not, according to these studies, something that inheres in individuals or groups as an essential part of their nature or psychology, but a concept that can change according to social forces and personal agency. ${ }^{2}$

Similar qualitative studies in an interactionist mode have recently examined the "performance" of race, class, and gender as interrelated concepts, emphasizing how race emerges through continuing social interaction and is constructed vis-à-vis other identities. This work emphasizes how race relies on other categories of difference and inequality to gain its meaning, and argues that race (along with class, gender, and other categories) is better understood as something one "does" rather than something one "has" (Best 2003; Bettie 2003; Moore 2002; West and Fenstermaker 1995). Race from this perspective is performed and ritualized through patterns of interaction-occasionally negotiated and altered, but more often reified and maintained as a set of expectations based on others' perceptions of "what someone is." This research has highlighted the social accountability and restrictions built into 
race-based perceptions. It has also allowed room for agency and change, often casting race (along with class, gender, sexuality, etc.) as actively performed and managed by people within certain socially determined constraints that can be negotiated by actors. ${ }^{3}$

However, in viewing race as a social construction, interactionist perspectives also remind us that physical identifiers compose the primary symbolic referent for the social meanings that become race (Lewis 2003; see also Haney López 1996). We tend to see performative aspects of race primarily where physical markers could be interpreted as ambiguous. But dark skin color, for example, places a much greater restriction on the options associated with enacting and interpreting race (Lewis 2003). Research exploring racialization through interpretations of physical difference has emphasized the role of power in constructing, and restricting, ideas about race. Haney López (1996), for example, documents how the court system historically relied on "common knowledge" explanations of racial categorization and used these to exclude from the privileges of whiteness those who appeared "different." While this once again underscores the social construction of race through everyday meanings, it also foregrounds the role of power in this process. Racial designations are more than just intriguing products of social construction-they are driven by power relations and result in very real patterns of inequality.

Thus, evidence from interactionist perspectives on race highlight the social construction of racial categorization, as well as the importance of these categories in influencing privileges and disadvantages. However, while this research forms an increasingly convincing argument for understanding how race is shaped by social interaction, such an understanding remains easier to contemplate theoretically than to employ in methodological practice. If racial identities of individuals and groups can change as they move through time or even as they move through various social contexts, how can we select any particular racial category (even if this is a series of categories) and call it a person's race? If race can be something that is done or performed, how can we impute a particular race onto someone we observe without making race appear as an individual essence rather than a social creation? Given the widespread deconstruction of the concept of race, research often affords comparatively little attention to how race is identified through methodological practice. Studies rarely reflect on how race has been recognized and "operationalized" methodologically, including in qualitative studies. Yet, an interactionist perspective suggests that race is not always simple and straightforward, particularly when physical markers might be considered socially ambiguous. Further, this perspective suggests that racial designations matter. Racial categories and understandings are exceedingly important for how people see themselves and react to others (May 2001). Thus, research methods for identifying these concepts should be considered equally important.

In what follows, I argue for greater transparency in how race is determined in qualitative studies and increased reflection on this concept as socially situated. I 
review two conventional approaches to identifying race in qualitative methods, researcher-described appearance and participant self-identification, and explore how both can be considered problematic. In this analysis, I use examples from recent and classic research reflecting my interest in education and youth. I do not intend to implicate these works as examples of "bad" research. To the contrary, I utilize these studies precisely because I consider them especially valuable contributions that I have used in my own research.

\section{RESEARCHER-DESCRIBED APPEARANCE}

Virtually any study, including those that deconstruct conventional understandings of race, begins with a relatively static notion of race to focus the research. For instance, a researcher might choose some racially defined population in which racial and ethnic identity appears interesting, or select a school or other organization based on some perception of the racial composition of its population. Such studies, and others that are less focused on race per se, begin with a notion of race that is not defined by those who will be studied. Rather, the researcher relies on prevailing racial definitions as defined by powerful institutions-newspaper reports, census data, school records, to name a few. Researchers typically couple these dominant views of the racial composition of research participants with the researcher's understandings of that group or groups based on their own past experience. It is only after the use of these outsider perceptions and definitions of race that fieldworkers might learn more about race in that setting and begin to see this concept in terms of insider meanings.

Often, however, researchers never plumb this insider view of race. Especially in observationally based studies, fieldworkers tend to describe people using extant racial categories based on how they appear to the fieldworker. Many studies do not fully describe this process of identifying race-a person simply "is" white or "is" Asian American, for example. A reader would assume that such categorization follows existing races as defined by the census, but methodologies do not often clarify the categories employed in this process and where ambiguities might arise. Although researchers often rely on their own interpretation of how physical characteristics translate into race, they do not describe this as an act of interpretation-race becomes simply what someone is without further elaboration. Thus, in many qualitative studies the procedure for determining race is not fully problematized or revealed. Most researchers appear to rely on a combination of what they pick up in the field and what they think of participants' appearances, but do not describe the specifics of this process, implicitly constructing it as trivial or based in common sense. This casual approach to race does not fully attend to how this complex concept is constructed, negotiated, and reaffirmed through ongoing interactions.

The process of determining participant race based almost solely on the researcher's outsider perspective exists particularly in observational studies of children 
and adolescents (I encountered this issue in my own research with middle-school children, described below). Many such studies do not interview children to explore their understandings of race and racial identity (for an exception, see Connolly 1998), and so must rely on "what they look like," or occasionally when children invoke race to describe themselves and others (see, e.g., Moore 2002; Van Ausdale and Feagin 2001). When the analysis does not focus on racial identity per se, however, children's use of racial concepts tends to be left out, and researcher-determined appearance remains the sole determination of race. Such studies based on observation of appearance alone privilege the researcher's perspective on race (although, as I discuss below, this should not be seen as wholly invalid), and can preclude or hinder the "researched" from naming themselves. Different people may perceive others differently in terms of race (see Hill 2002), but researchers often position their own perspective as primary. This raises the possibility that the racial label an author applies to a participant might not necessarily match what that person considers his or her race to be, or might not capture how participants actively construct racial boundaries and identities.

Longer-term ethnographies allow for fieldworkers to gain a richer depth of understanding regarding the meanings of race in the context studied. Ethnographies, in my estimation, work best in identifying race based on insider meanings and tracing how ideas about race emerge through ongoing interaction. However, many ethnographies rely initially on the researcher's a priori understanding of race. Especially at first, the ethnographer often enters the field with a predetermined understanding of the racial composition of that setting, and this guides their approach to racial concepts there.

In his book Ain't No Makin' It, Jay MacLeod ([1987] 1995) uses census data to describe the racial composition of the neighborhood in which he locates his study. Based on these data, he describes the area as mostly white, and a quarter "black," although the second edition of his book amends this to "African American." His ethnography follows the experiences of two groups of boys in this neighborhoodone described as predominately black (the Brothers) and the other as predominately white (the Hallway Hangers). Although MacLeod expertly shows how racism and racial tension characterized the life experiences of the two groups, he does not explore the participants' own sense of racial identity. This may have been important for understanding the achievement orientation of the Brothers (at least one of whom we know is a first-generation Caribbean immigrant), who might not have necessarily seen themselves as "black" or identified with African Americans per se (see Waters 1999). It may have also been important for the Hallway Hangers, who like other poor, inner-city whites, might have seen themselves as being on the margins of "whiteness" (see Hartigan 1999). Such an analysis could substantially complicate race, but MacLeod's categorizations of physical characteristics ultimately define this concept rather neatly, which implicitly frames "being white" and "being black" as static qualities that inhere in individuals, rather than ways of being that people work to inhabit and construct boundaries for. 
One way around the dilemma of categorizing race based on appearance is to simply ask people to name their own racial identity. Many researchers rely on this method to gain more of an understanding of participants' racial identities and avoid imposing outside categories on those being studied. However, as I argue, this approach does not solve the problem of identifying race.

\section{PARTICIPANT SELF-IDENTIFICATION}

Asking respondents how they identify themselves racially is probably the most prevalent and convincing way to identify race. Survey-based research, which composes the bulk of studies published in sociological journals, widely uses this approach, although sometimes survey interviewers code respondents racially based on how they appear to the interviewer. Qualitative studies, especially those using indepth interviews, employ a similar approach with a notable exception. Qualitative interviewers typically allow interviewees to name their own racial identity rather than choose from predetermined categories. This practice at first appears to be a panacea for identifying race-what better way exists to assess race than simply to ask respondents, in an open-ended question, what they think? But it is precisely because this method seems so straightforward that problems arise.

Especially when these identities are not probed, race, as defined by the respondent at one point in time, can be framed as an individual, psychological essence devoid of context and not assessed in terms of ongoing interaction. This approach (again, only when the response is not probed and evaluated across time) tends to freeze race and fails to describe it completely as a social construction because the activity of constructing is not elaborated. When used in this way, race tends to take on the properties of an independent variable-something the researcher enters into the analysis to evaluate if it has an "effect." If responses to other questions differ by self-reported race, one assumes race to be important; if not, analysts tend to deem it insignificant and minimize its impact. Interestingly, this occurs especially when respondents in a study have reported themselves to be white. Although interest is growing in assessing how race privileges white people, researchers still often frame race as a nonissue when respondents have claimed whiteness, especially if they compose the bulk of the sample. By not probing race and racial identity in the lives of those reporting themselves to be white, and simply accepting these self-reports as race, researchers run the risk of missing the importance of race in terms of how it is constructed, including how this construction can result in modes of privilege (e.g., Frankenberg 1993; Dyer 1997).

Basing race on self-reporting can cast this concept as something people "have" that causes them to interact in a certain way, rather than something produced and maintained by those interactions (see Williams 1991 for a similar argument regarding gender). This can extract race from social context and other categories of difference that influence its meaning. A recent American Sociological Review article by Annette Lareau (2002) explores child rearing in black and white families of various 
social class backgrounds. While the author marshals meticulous data for this project and explores child rearing in unprecedented depth, race is not fully defined, especially in relation to class. This article appears to use a combination of school records and participant self-identification to determine race. After this initial determination the author does not probe race much further, except to explore how a black middleclass family teaches their son about racism and racial identity. The view of race in this sense is fixed by what the respondents initially report-not by what others think or how race emerges from the social interactions of respondents among themselves and others. This allows the author to conclude that race had "less of an impact" than social class on child rearing and how families approached institutions such as school and medical organizations. Because race is viewed as static, it can be compared against social class as a variable, and not explored as it interacts with class through social engagement. Thus, we lose a sense of race as potentially ambiguous, contested, created and re-created through a social process (that undoubtedly intersects with social class constructions).

Self-identity alone also fails to describe how others view that person in terms of their race. Again, this practice abstracts race from the social context that gives it meaning. What an individual considers themselves to be is arguably less important socially than what others around that person consider them to be. Because of the impact of social forces and the development of self-concept through social interaction, an individual's racial identity usually matches how others see them (see Cooley 1902). Occasionally this match is imperfect, however. One common example exists in the phenomenon of "passing," especially among people whose physical appearance places them on the margins of racial categories. Individuals may see themselves as "really" one race but actively attempt to present themselves as another, and do so effectively enough to "pass" as that other race. Or individuals may see themselves as a particular race or ethnicity but fail to convince others that this "really" is their racial/ethnic background. Individuals of Latino background, for instance, might consider themselves white but might be seen by others as Hispanic or Mexican. Perhaps in another setting, another country, or another part of the United States, they were once seen as white, but in their present social situation they might not be seen this way. To consider them just white, then, minimizes an entire social context in which a person's physical appearance gains meaning and constrains and encourages certain actions. By only assessing how interviewees see themselves in terms of race, a researcher does not consider how others see them. Yet the perceptions of others in that individual's social settings compose one of the most important factors in how that individual's physical features influence their interactions in that setting - a crucial part of understanding the impact of race.

Both of these widespread methods for determining racial background in qualitative research-researcher observation and participant self-identification-are not sufficient in and of themselves for capturing the elusive concept of race. At worst, each method risks reifying race as an essential quality of individuals, rather than accounting for the discourses and interactions surrounding racialized meanings in 
a particular context. At best, these methods used alone present only one side of a mosaic of meanings and practices that constitute race. Skin color, hair type, selfidentification, other's perceptions, and so forth by themselves do not describe race. Rather, as much symbolic interactionist informed research already suggests, race stems from a dynamic combination of these factors as actors create and recreate meanings for this concept through continuing social interaction. This does not mean that physical markers and power do not play considerable roles in this process. But by remaining aware of the dynamic and multifaceted composition of race, we can approach this concept through research in ways that avoid stereotyping, essentializing, and trivializing its impact, and overlooking its construction through other modes of difference and inequality. This is important for research that focuses primarily on race as well as that which does not, because race, class, gender, and other areas of inequality consistently intersect (Collins 1990) and seep into virtually all spaces of daily life, composing the historical framework from which we guide our future actions.

As I have mentioned, in critiquing the identification of race in current research, I am not attempting to indict this research as inherently bad or wrong. Nor do I pretend that my own research has fully accounted for these problems. Indeed, I arrive at this critique primarily because of the difficulties and gaps I experienced in identifying race in my own research, which I describe next. I have since finished this research project, and incorporated as much of my understanding of the malleability of race as possible into my analysis. However, I fear that my initial preconceptions of the relative straightforwardness of race placed some limits on how I was able to understand race in this setting, especially at the outset of my fieldwork.

\section{UNDERSTANDING RACE IN AN URBAN SCHOOL}

My research focused on white students in a predominately nonwhite middle school located in a large urban area in Texas. I conducted this study over the course of two school years, during which I observed classrooms, interviewed teachers and administrators, tutored students, and attended various after-school activities and events. I chose the school in part because its records reflected the type of student composition I sought -47 percent African American, 40 percent Latino, 9 percent Asian American, 4 percent white, with 60 percent of students receiving free or reducedprice lunch (indicating economic disadvantage). As soon as I began observing at the school, however, I learned that the racial categories of students were much neater in statistical abstraction than they were in the actual daily experiences of school life. In my naive excitement to identify and study white students in this predominately nonwhite context, I had no idea how difficult it would be to simply identify who was white and who was African American, Latino, Asian American-not to mention other categories not listed in "official" records.

Similar to May (2001), I found that my past racialized experiences undoubtedly framed my perceptions of race and whiteness in this school. This process of 
researching race heightened my awareness of my own whiteness and middle-classness (see also Best 2003). Understandings of my own "white" racial identity, which I had (wrongly) learned to see as a taken-for-granted, inherent quality, perhaps hindered me from anticipating the fluidity of race in this multiracial and ethnic context. Some of the students at this school could be considered multiracial in a conventional sense (by which I mean having immediate ancestry from more than one racial category). But most could be considered multiracial in another, less biological sense of the word. Many of these students shared ways of talking, dressing, interacting, knowing, and being friends across stereotypical racial boundaries. To be sure, many also policed and reified essentialized borders between races, but this practice seemed to mark precisely where race became most ambiguous and often succeeded in problematizing race further from my perspective.

Of course, when students had physical markers such as dark skin and black hair, or light skin and blonde hair, racial categorization appeared clear to myself and others. But in far more cases than I could have anticipated, such clarity did not appear, and the fusion of racial styles and identities at the school added layers of complexity. For many of the minority white students especially, the racial identities they performed deviated significantly from what I would have considered white based on past experiences of my own racial identity, and this complicated how I identified them in terms of race in my field notes. In many cases, the "passing" as nonwhite by these students fooled me. However, as I learned more about this setting, I realized that it was less important to understand these students in terms of a "true," static race, and more important to understand the meaning of their particular embodiments of race and whiteness from various perspectives.

One example of a student I had difficulty classifying in terms of race was named Lisa (a pseudonym, as are all names I use). I observed Lisa in the first classroom I entered at the school. As I looked across this classroom, guided by my interest in interactions pertaining to race in this school setting, I intended to describe the different students in terms of their racial backgrounds, along with gender, clothing, names, personality, and so forth. Because this was an advanced-level class, I especially wanted to determine how many white students it contained, because one of my main research questions asked if white students tended to be tracked into higher-level classes. When I told a colleague afterward about observing the class, the first thing she asked (knowing my research topic) was how many white students I observed. While this seemed a straightforward question to her and myself, I could not answer it. Indeed, that first day I hesitated to mark race in my field notes at all-I remained unsure not only about Lisa but about several other students in the class, whom I could not describe as white, or Latino, or African American with absolute clarity.

Over the course of my first few weeks of observation such "problems" persisted. I had much more trouble identifying who was white than I had prepared myself for. This pertained to several students, including Lisa, whom I had seen in a few different classes during those first weeks. Lisa had light skin but dark hair and features. 
She hung out almost exclusively with students I classified as African American and spoke with a cadence and accent similar to her black friends, which many would characterize as "Black English" (see Labov 1972; Dillard 1972; Smitherman 1977, 2000). I decided initially to classify her as white. However, at first, perhaps in my zeal to identify white students, I tended to overclassify students as white. I recorded some lighter-skinned black and Latino students as white initially, but soon changed this after further observation. I changed Lisa's designation eventually as wellmultiracial (in this case meaning part white and part African American)-after she began wearing her hair in tightly braided cornrows identical to a hairstyle preferred by many black girls at the school. This, along with the fact that she shared so many friendships and interactive styles with African American students, made her appear more black according to my perceptions.

However, I changed my designation of Lisa's race once again after I distributed a survey form to all students. One of the questions on this survey asked the students to identify their race. I provided the standard choices used in school records (African American/Black, Latino/Hispanic, Asian, White/Anglo, Native American), explaining that students could choose any combination, and I also included an "Other" designation followed by a space for them to write in their own choice. Lisa circled just "White" on this form, without selecting any other category or writing in a different choice. I eventually matched this with school records, which also classified her as "white." In addition, I asked a few teachers what they thought of Lisa's race. Although this question felt awkward, they also described some difficulty in understanding her race, indicating that they saw her as technically white, but with some ambiguity.

The story of how Lisa became white exemplifies the difficulty that often attends classifying people in terms of race. I eventually came to classify Lisa as white, but this did little to describe how others interpreted her whiteness and reacted to her in terms of this. Her self-designation (albeit just on a survey) did little to improve a description of how she embodied whiteness. She, like many other youth in this setting, chose a particular racial category to describe herself, but embodied this designation in a way that went beyond what that category might typically imply. In their interactions in this setting, youth often transgressed extant racial boundaries, giving new meanings to race, including whiteness. So was Lisa white? This was certainly the best choice from among prevailing, mutually exclusive racial categories. However, to end her race there, and not also describe how Lisa pushed the boundaries of this category for herself and others, would not only ignore the tortuous process through which I as a researcher arrived at this conclusion but also reify her whiteness as a fixed essence rather than something she and others constructed and negotiated.

I also occasionally struggled in my research to classify students I later came to understand as "Hispanic" or "African American." In some cases, the data I collected were inconsistent. This pertained to a student named Thomas. I eventually came to mark Thomas as "Hispanic" based on his Spanish surname and his survey response. He circled just "Hispanic" on his survey form (and not "Latino," although 
the form connected the terms by a backslash). He did not choose any other racial category in addition to Hispanic. Before I collected his response on this survey, however, I assured myself that he must be white (by this I mean non-Hispanic white, or "Anglo" as many used the term in this setting, where "Hispanic" was used as a racial category rather than an ethnic category). I undoubtedly arrived at this conclusion, admittedly, because of Thomas's stereotypically white interactive style. Thomas always wore a tightly tucked-in shirt and Dockers brand pants (the school had a uniform dress code that required a tucked-in shirt and khaki-colored pants). This differed from most other boys at the school who preferred Dickies pants (a brand marketed for blue-collar work) and often resisted wearing their shirts tucked in. Thomas had light skin and light, reddish-hued hair that he wore neatly parted on one side with small bangs (another uncommon practice for boys in this setting, who typically wore their hair shaved or very short, without parts). He always spoke using dominant, what could be called white patterns of English, with no hint of a Latino or Southern accent, and no phrases or cadence characteristic of how African American or Latino students at the school spoke.

I began to question my initial "coding" of Thomas's race, however, after hearing a teacher use his last name-one of Spanish origin - in a class. I asked the teacher if she thought Thomas was Hispanic, and confessed that I had considered him white. She told me she considered him Hispanic but agreed with the difficulty of figuring out race in this setting and suggested that I would find most of the kids to be "multiple" in terms of race. This teacher's assessment turned out to be very true for many students, including Thomas, because I later learned that his official designation in school records was white. Thus, my initial determination based on appearance and interactive style categorized Thomas as white, and this matched school records. However, Thomas, based on his survey, considered himself Hispanic, and his teachers also considered him Hispanic and not white. So, was Thomas white? Classifying him as white would have been consistent with my observations and with school records, which reported test scores by race, and would have included Thomas's scores in the white subgroup. However, it would have been inconsistent with how teachers saw him and how he saw himself, at least at the point in time when I conducted the survey.

Thomas probably paralleled the experiences of many multiracial students described by Harris and Sim (2002) who chose one race when surveyed at school and a different race when surveyed at home. However, simply describing Thomas as multiracial does not fully express how different facets of his race became illuminated according to different perspectives. A multiracial designation, or describing race in terms of multiple pre-set racial categories, also does little to explore how race, especially for those who may be on the margins of categories, shifts and re-creates its meaning through ongoing interaction. Classifying someone as multiracial as an abstracted racial category can ironically become just another way to make race seem like a fixed (and sometimes biologically based) essence. In the end, I designated Thomas as Hispanic, giving the most weight to his own identification on the 
survey form and how teachers saw him. This designation was somewhat arbitrary, however, and along with it I also described how he projected a stereotypically white persona to myself and others in this setting that complicated this identity. Through assessing different perspectives on Thomas's race (including my own outsider-informed view), I did not come to understand his "real" race. Instead, I came to understand enough about it to conclude that such a quest would be quixotic and that it made more sense to describe interpretations of his race from various perspectives.

My assessment of Thomas's race (as well as Lisa's and other students') might have been further elaborated had I chosen to interview students and their parents in-depth and ask them about racial identity. I do not pretend to have covered all the bases in determining each student's race. As with most research, my analysis could only capture slices from the complex of meanings surrounding someone's race. Had I conducted such in-depth interviews, however, I still would not have uncovered Thomas's "real" race, but just provided additional perspectives from which to interpret it.

It should be acknowledged that the context of the multiracial youth culture in this school allowed for more flexibility in racial performance than might exist in other contexts, among other individuals. The youth in this school had not fully incorporated prevailing societal discourses on race into their realities, and this allowed them to negotiate new boundaries for racial categories. For the adult teachers in the same school, virtually all of whom were African American or white, race appeared more solidified. These teachers spoke of themselves and others in terms of prevailing racial categories in that context (black, white, Hispanic, Asian), and did not use the more creative categories I witnessed among the students, such as "mixed" (claiming a merger of identities) and "white chocolate" (claiming white skin, but a black identity). This makes sense because the adults had far more exposure to the dominant, extralocal discourse of race and racial categories. This exposure undoubtedly shaped them to accept a certain race as a relatively fixed self-concept, and systematically reaffirm this through following societal expectations. ${ }^{4}$

\section{CONCLUSION}

Symbolic interactionism, by attending closely to the social construction of various modes of inequality, provides a crucial framework for researching the complexity of race. But much empirical research, including qualitative study, does not always proceed in a way that follows this insightful perspective. In an article about race and qualitative methodology, De Andrade (2000:287) argues against approaches to studying race in which "race takes on a static and one-dimensional tone." While the author specifically addresses insider-outsider issues and the role of the researcher, this perspective can be broadened to evaluating how researchers identify race in general. In this article I have argued that race is often determined perfunctorily through conventional approaches and not given sufficient depth. While marking 
race in one particular way might not be "wrong," it is certainly one-dimensional and typically noncritical. Based on my own research difficulties in determining race, I am skeptical of methodological conventions that confidently state a participant's race with little or no reflection on how this was determined. By framing such a research process as easy, this appears to downplay the complicated social process of constructing race through ongoing interaction.

Of course, we must have a vocabulary for identifying people in terms of race, and should acknowledge that most people see themselves and others in terms of prevailing racial categories, with considerable agreement. Indeed, as I describe in my research examples above, I retain the designation "white" and other prevailing racial categories. Such categories have important social meanings, and I do not wish to problematize race to the point that we hesitate to articulate it at all, because to do so would ignore a major mode of social inequality and identity. I also acknowledge that this inequality and identity is often based on "what people look like" and "how they see themselves"- the two primary ways qualitative research has tended to determine race. However, without a context for understanding race as socially situated, these means of racial classification provide little depth and can implicitly construct race as narrow and simplistic. What someone selects on a survey form, what they tell people in an interview, or how they appear to others, might each compose one facet of race, but by themselves do not always indicate the full meaning of this concept.

So how do we research race in a way that guards against reifying this social construction while still identifying racial background and exploring its impacts? Informed by an interactionist perspective, I propose two ways to work toward a possible solution. First, researchers should always acknowledge how they chose to identify race and the means they have used to decide racial characterizations. Various methods for identifying race each suggest a particular aspect of this concept, which reveals a certain truth about it. Self-identification, even if on a survey or interview at one point in time, gives us a certain view of how individuals see themselves in terms of their race. Researcher observation, even in the beginning stages of fieldwork, can represent an important outsider view of race, providing a slightly different perspective from insiders. How research participants see other participants in terms of their race-a less-utilized approach — composes an additional view of the social definitions of race. Other sources might provide other ways of understanding this concept. None of these in and of themselves should be employed as if they represent race in full, but if one is the only source available to the researcher it could still be used with the acknowledgment that it reflects only a certain angle on race. This leaves the door open for research that critiques racism (and other modes of inequality) but might not be privy to an in-depth analysis of race per se. Studies should be sure to acknowledge what they lack in their determination of race, however, and not suggest one aspect reflects the concept as a whole.

Second, researchers should pay close attention to the influence of particular racialized contexts, and how people speak and enact race in those contexts. In some 
contexts, such as the peer culture of the school I studied and particularly for students whose physical features could be considered ambiguous, it might make sense to view race more as a product of interactional negotiation rather than a characteristic. In other contexts, where race is less ambiguous and has come to characterize relatively stable patterns of interaction and identity, it might make sense to describe race as more of an attribute. Such contexts might include racial settings considered predominately black and white, particularly among adults, where prevailing racial categories tend to be reproduced rather than negotiated. However, researchers should acknowledge that even where race appears simple and static, it remains so only because people reaffirm it in a relatively consistent way, not because it inheres in them as an essential quality. Further, if we identify contexts and participants where race has more fixity, this is not necessarily because we have gained a more valid or accurate understanding of race. The task for researchers should not be to uncover the truth of each person's race in their studies but to try to understand race from as many angles as possible and reveal the processes through which they arrived at a particular determination. Through a more critical reflection of this process, researchers can acknowledge and explore the socially situated basis for race and racial meanings in all contexts.

Political contexts and ramifications are also important for guiding how we research race. When students or nonacademic friends ask me about the impact of racial inequality in society, I often invoke data showing racial disparities in health, educational attainment, earnings, and so forth. These data are all based on highly simplistic conceptualizations of race. Yet, perhaps because of their simplicity, they remain valuable for explaining inequality in certain modes we consider racial and therefore accomplish a certain politically useful purpose. However, such uses of race as an attribute, or independent variable, still only capture the socially constrained, dominant discourse on race and reflect the inequality apparent in this discourse. As an interactionist framework suggests, such uses do not really represent race in all its complexity-they just show how people who have identified with dominant racial categories may have distinctive, unequal life experiences, manifested in their daily interactions in racialized contexts (see Anderson and Snow 2001, and Schwalbe et al. 2000, for reviews of interactionist approaches to inequality, including race). Such contexts and identities continue to be produced and maintained through ongoing interaction that provides them their impact and meaning.

Thus, researchers can work toward clarifying the dilemmas of race by being more reflexive and transparent when identifying this concept and attending closely to the contexts in which race is enacted and deployed. Symbolic interactionist approaches provide the ideal way to accomplish both goals through assessing race as people actually construct it in their daily lives. This research can also highlight how particular constructions of race work through other categories such as gender, social class, and sexuality to obtain meaning and maintain inequality. Qualitative methods can uniquely capture the changeable and fickle work of race, documenting how participants struggle against racial structures and develop racial understandings. But as I 
have attempted to show, race can be minimized and simplified even in this research. Qualitative work from an interactionist perspective should strive to document how race was inhabited, managed, and used by participants in particular settings. Through studying the construction of race as it emerges in social context, such research can provide a uniquely rich understanding of this complex but indispensable concept.

Acknowledgments: I thank Christine Williams and Jennifer Pierce for helpful advice on earlier drafts. I also thank the staff and students at Matthews Middle School (a pseudonym) for sharing their time and thoughts with me.

\section{NOTES}

1. Although some of these studies use the word ethnicity instead of race, they look at the development and maintenance of census-defined racial categories-Asian American, Native American, white. This shows the social construction of both race and ethnicity, because what constitutes a race versus an ethnicity changes across time and space. For this reason, many scholars combine race and ethnicity into a single term such as racial/ethnic, or ethnoracial (see Brodkin 1998; Foley 1997).

2. Quantitative work has recently added to this literature. Harris and Sim (2002), for instance, find that many adolescents in the ADD health survey chose different racial categories in different contexts. Many of these youth selected a different race to describe themselves when interviewed at home than they did when interviewed at school. This supports qualitatively based arguments for understanding race as shifting and situational.

3. Collins et al. (1995) critique the freedom implied by this view of race as something "done" or "accomplished," but do not argue against understanding race as a social construction.

4. It should also be noted that U.S. society tends to mark nonwhites as racialized "others" and link negative reactions to groups with darker skin color, which can incur more constraints and materiality associated with race for members of these groups. Thus, because of historical and contemporary racism based on skin color, African Americans, for example, might generate a sense of collective experience that regularly connects and identifies them to a certain racialized mode of experience, making the expression of race more overt (see, e.g., May 2000).

\section{REFERENCES}

Anderson, Leon and David A. Snow. 2001. "Inequality and the Self: Exploring Connections from an Interactionist Perspective." Symbolic Interaction 24:395-406.

Best, Amy L. 2003. "Doing Race in the Context of Feminist Interviewing: Constructing Whiteness through Talk." Qualitative Inquiry 9:895-914.

Bettie, Julie. 2003. Women without Class: Girls, Race, and Identity. Berkeley: University of California Press.

Blumer, Herbert. 1958. "Race Prejudice as a Sense of Group Position.” Pacific Sociological Review 1:3-7.

1969. Symbolic Interactionism: Perspective and Method. Berkeley: University of California Press.

Brodkin, Karen. 1998. How the Jews Became White Folks and What That Says about Race in America. New Brunswick, NJ: Rutgers University Press. 
Collins, Patricia Hill. 1990. Black Feminist Thought: Knowledge, Consciousness, and the Politics of Empowerment. New York: Routledge.

Collins, Patricia Hill, Lionel Maldonado, Dana Takagi, Barrie Thorne, Lynne Weber, and Howard Winant. 1995. "Symposium: On West and Fenstermaker's 'Doing Difference.” Gender \& Society 9:491-513.

Connolly, Paul. 1998. Racism, Gender Identities, and Young Children: Social Relations in a MultiEthnic, Inner-City Primary School. London: Routledge.

Cooley, Charles Horton.1902. Human Nature and the Social Order. New York: Charles Scribner's Sons.

Cooper, Richard. 1984. "A Note on the Biological Concept of Race and Its Application in Epidemiological Research." American Heart Journal 108:715-23.

De Andrade, Lelia Lomba. 2000. "Negotiating from the Inside: Constructing Racial and Ethnic Identity in Qualitative Research.” Journal of Contemporary Ethnography 29:268-90.

Dillard, Joey L. 1972. Black English: Its History and Usage in the United States. New York: Random House.

Dyer, Richard. 1997. White. London: Routledge.

Espiritu, Yen Le. 1992. Asian American Panethnicity: Bridging Institutions and Identities. Philadelphia: Temple University Press.

Foley, Neil. 1997. The White Scourge: Mexicans, Blacks, and Poor Whites in Texas Cotton Culture. Berkeley: University of California Press.

Frankenberg, Ruth. 1993. White Women, Race Matters: The Social Construction of Whiteness. Minneapolis: University of Minnesota Press.

Goodman, Alan H. 2000. "Why Genes Don't Count (for Racial Differences in Health)." American Journal of Public Health 90:1699-702.

Graves, Joseph L., Jr. 2001. The Emperor's New Clothes: Biological Theories of Race at the Millennium. New Brunswick, NJ: Rutgers University Press.

Hall, Stuart. 1986. "Gramsci's Relevance for the Study of Race and Ethnicity." Journal of Communication Inquiry 10:5-27.

Haney López, Ian F. 1996. White by Law: The Legal Construction of Race. New York: New York University Press.

Harris, David R. and Jeremiah J. Sim. 2002. "Who Is Multiracial? Assessing the Complexity of Lived Race." American Sociological Review 67:614-27.

Hartigan, John, Jr. 1999. Racial Situations: Class Predicaments of Whiteness in Detroit. Princeton, NJ: Princeton University Press.

Hill, Mark E. 2002. "Race of the Interviewer and Perception of Skin Color: Evidence from the Multi-City Study of Urban Inequality." American Sociological Review 67:99-108.

Labov, William. 1972. Language in the Inner City: Studies in the Black English Vernacular. Philadelphia: University of Pennsylvania Press.

Lareau, Annette. 2002. "Invisible Inequality: Social Class and Childrearing in Black Families and White Families." American Sociological Review 67:747-76.

Lewis, Amanda E. 2003. Race in the Schoolyard: Negotiating the Color Line in Classrooms and Communities. New Brunswick: Rutgers University Press.

MacLeod, Jay. [1987] 1995. Ain't No Makin' It. 2nd ed. Boulder, CO: Westview.

May, Reuben A. Buford. 2000. "Race Talk and Local Collective Memory among African American Men in a Neighborhood Tavern." Qualitative Sociology 23:201-14.

. 2001. "'The Sid Cartwright Incident and More': An African American Male's Interpretive Narrative of Interracial Encounters at the University of Chicago." Studies in Symbolic Interaction 24:75-100.

Moore, Valerie A. 2002. “The Collaborative Emergence of Race in Children's Play: A Case Study of Two Summer Camps." Social Problems 49:58-78.

Nagel, Joane. 1994. "Constructing Ethnicity: Creating and Recreating Ethnic Identity and Culture." Social Problems 41:152-76. 
1995. "American Indian Ethnic Renewal: Politics and the Resurgence of Identity." American Sociological Review 60:947-65.

Omi, Michael and Howard Winant. [1986] 1994. Racial Formation in the United States: From the 1960s to the 1980s. 2nd ed. New York: Routledge and Kegan Paul.

Schwalbe, Michael, Sandra Godwin, Daphne Holden, Douglas Schrock, Shealy Thompson, and Michele Wolkomir. 2000. "Generic Processes in the Reproduction of Inequality: An Interactionist Analysis." Social Forces 79:419-52.

Smedley, Audrey. 1993. Race in North America: Origin and Evolution of a Worldview. San Francisco: Westview.

Smitherman, Geneva. 1977. Talkin and Testifyin: The Language of Black America. Boston: Houghton Mifflin.

- 2000. Talkin That Talk: Language, Culture, and Education in African America. New York: Routledge.

Spickard, Paul and Rowena Fong. 1995. "Pacific Islander Americans and Multiethnicity: A Vision of America's Future?" Social Forces 73:1365-83.

Van Ausdale, Debra and Joe R. Feagin. 2001. The First R: How Children Learn Race and Racism. New York: Rowman and Littlefield.

Waters, Mary C. 1990. Ethnic Options: Choosing Identities in America. Berkeley: University of California Press.

- 1999. Black Identities: West Indian Immigrant Dreams and American Realities. Cambridge, MA: Harvard University Press.

West, Candace and Sarah Fenstermaker. 1995. "Doing Difference." Gender \& Society 9:8-37.

Williams, Christine L. 1991. "Case Studies and the Sociology of Gender." Pp. 224-43 in A Case for the Case Study, edited by J. Feagin, A. Orum, and G. Sjoberg. Chapel Hill: University of North Carolina Press.

Zuberi, Tukufu. 2001. Thicker Than Blood: How Racial Statistics Lie. Minneapolis: University of Minnesota Press. 
